\title{
KAJIAN PERANCANGAN PASAR MILENIAL: PASAR YANG MERESPON PERILAKU MILENIAL
}

\author{
Rudy Lim ${ }^{1)}$, J. M. Joko Priyono Santoso ${ }^{2)}$
}

1)Program Studi S1 Arsitektur, Fakultas Teknik, Universitas Tarumanagara, Rud120597@gmail.com
2) Program Studi S1 Arsitektur, Fakultas Teknik, Universitas Tarumanagara, jokop.ft@untar.ac.id

\begin{abstract}
Abstrak
Pasar mulai kehilangan bentuk fisiknya akibat kemunculan pasar online, yang disebabkan oleh perilaku millennial yang menuntut segalanya serba instant. Pasar online tidak selamanya baik karena banyak masalah yang ditimbulkan oleh pasar online, seperti penipuan kualitas barang, kasus cybercrime seperti pembajakan akun online, keamanan barang yang kurang terjamin dalam proses pengiriman, dan masih banyak lainnya. Berbagai masalah yang ditimbulkan pasar online tersebut disebabkan kurangnya interaksi langsung dengan produk atau penjual, sehingga dapat disimpulkan bahwa pasar masih membutuhkan bentuk fisik. Metode yang dipakai untuk menjawab issue ini berawal dari proses pengumpulan data mengenai kebiasaan millennial dan issue yang ditimbulkannya terutama terhadap perkembangan pasar. Kemudian metode matriks digunakan untuk menghubungkan data-data yang telah dikumpulkan sampai didapatkan hasil dengan jawaban yang beragam. Terakhir dilakukan berbagai eksperimen massing beserta konsepnya sehingga tercipta berbagai opsi dan pengembangan desain yang lebih. Melalui metode tersebut dicapai hasil berupa program-program interaktif yang memberikan pengalaman berbeda bagi millennial sehingga millennial akan tertarik untuk mengalami ruang yang dibentuk oleh pasar millennial. Metode eksperimen desain juga menghasilkan sebuah bentuk yang memberikan identitas kepada lingkungan sekitar site yang kekurangan landmark. Kesimpulan dari proyek ini adalah Pasar Millennial: "Pasar yang merespon perilaku millennial" beserta program-program didalamnya yang berupa traditional market, menu digital gallery, e-clothing store, food market dan gym. Program-program tersebut merupakan program yang menjawab segala kebutuhan interaktif millennial, dan membuktikan bahwa millennial masih membutuhkan ruang fisik.
\end{abstract}

\begin{abstract}
The market began to lose its physical form due to the emergence of the online market, which was caused by the behavior of millennials who demanded everything to be instant. The online market is not always good because there are many problems caused by the online market, such as quality goods fraud, cybercrime cases such as online account hijacking, goods security that is not guaranteed in the shipping process, and many others. The various problems posed by the online market are caused by a lack of direct interaction with the product or seller, so it can be concluded that the market still requires physical form. The method used to answer this issue begins with the process of collecting data on millennial habits and the issues that arise are mainly due to market developments. Then the matrix method is used to connect the data that has been collected until the results are obtained with diverse answers. Lastly, various massing experiments and concepts were carried out to create more options and develop more designs. Through this method the results are in the form of interactive programs that provide a different experience for the millennials so that the millennials will be interested in experiencing the space formed by the millennial market. The design experiment method also produces a form that gives identity to the environment around the site that lacks landmarks. The conclusion of this project is the Millennial Market: "Markets that respond to millennial behavior" along with programs in the form of traditional markets, digital gallery menus, e-clothing stores, food markets and gyms. These programs are programs that answer all millennial interactive needs, and prove that the millennials still need physical space.
\end{abstract}




\section{PENDAHULUAN}

Perilaku millennial yang menuntut segalanya serba instant melahirkan pasar online, yang kemudian menimbulkan suatu fenomena dimana pasar mulai kehilangan bentuk fisiknya. Fenomena tersebut tidak hanya terjadi di Indonesia, namun di seluruh dunia, fenomena tersebut bernama "Retail Apocalypse" dimana retail-retail bangkrut karena tidak mampu bersaing dengan pasar online.

Tidak bisa dipungkiri bahwa pasar online terlihat superior, terutama di era millennial yang menuntut segalanya serba instant, namun pasar online menimbulkan issue yang juga lebih superior. Penipuan sudah menjadi sebuah issue yang cukup berat dalam sistem pasar online, penipuan kualitas barang dimana barang yang sampai tidak memiliki kualitas yang sama atau bahkan memiliki visual yang berbeda. Pasar Online pun memiliki issue lain seputar keamanan barang atau bahkan pembajakan akun secara online yang termasuk sebuah cybercrime. Issueissue tersebut menciptakan ekspektasi dan realita yang jauh berbeda dalam proses transaksi pasar online. Melihat hal tersebut muncul pertanyaan, apakah pasar berkembang ke arah yang tepat?

Perkembangan pasar yang menghilangkan bentuk fisik bukanlah langkah yang tepat, atau lebih tepatnya terlalu cepat. Pasar masih membutuhkan bentuk fisik, hal ini dibuktikan oleh issue yang dilahirkan oleh pasar online yang terjadi karena minimnya interaksi langsung dengan produk ataupun penjual secara langsung.

Proyek ini bertujuan untuk membangun pasar fisik yang interaktif dan dapat merespon perilaku millennial, karena pasar masih membutuhkan kontak social antara individu, baik penjual-pembeli, penjual-penjual ataupun pembeli-pembeli. Pasar perlu menyediakan kontak fisik terhadap produk dan tidak hanya kontak fisik dengan layar handphone. Pasar masih dibutuhkan untuk membangun rasa percaya antara masyarakat. Pasar jaman millennial tidak hanya menjadi tempat jual-beli barang, namun pasar juga harus menjadi symbol kehidupan social bagi lingkungan sekitarnya. Integrasi dengan teknologi adalah sebuah keharusan, namun Interaksi social merupakan elemen yang tidak boleh hilang dari kehidupan manusia generasi manapun.

\section{KAJIAN LITERATUR}

\section{Millennial}

Generasi Millennial adalah generasi yang lahir pada tahun 1981-1995 atau 1981-2000 dan merupakan generasi yang benar-benar berbeda dibandingkan generasi generasi sebelumnya. Generasi Millennial merupakan generasi setelah generasi transisi yaitu Gen X, hal ini dipengaruhi oleh globalisasi dan perkembangan teknologi.

Generasi millennial di Indonesia sendiri menurut nasional kompas saat ini merupakan generasi dengan populasi dominan di Indonesia saat ini. Tercatat kurang lebih 34,45\% jumlah penduduk di Indonesia merupakan generasi millennial. Millennial akan berperan besar atas pesatnya perkembangan teknologi dan inovasi yang tidak ada habisnya, karena millennial memiliki pola pikir out of the box dan kebiasaan yang serba instant, millennial akan menentukan masa depan dunia dan menyelesaikan misi-misi yang tidak dapat diselesaikan generasi sebelumnya, juga menyelesaikan masalah yang diperbuat generasi sebelumnya.

Perilaku, kebiasaan dan sikap millennial mempengaruhi berbagai aspek desain dalam arsitektur, baik itu mengubahnya maupun menghancurkannya. Sebagai contohnya tipologi office berubah dan berkembang secara signifikan, muncul program baru pada office yang 
memberi nilai tersendiri bagi perkembangan tipologi. Pasar merupakan contoh tipologi atau arsitektur yang berada dalam bahaya, millennial berkontribusi besar atas kehadiran pasar online yang membuat eksistensi pasar secara fisik atau arsitektur berada dalam bahaya.

\section{Lifestyle Millennial}

Lifestyle mencakup berbagai aspek, tidak hanya Lifestyle serba instant, millennial memiliki berbagai kebiasaan yang berbeda dengan generasi sebelumnya. Kebiasaan makan, kesadaran akan kesehatan (dari makanan atau aktivitas olahraga), dan lifestyle konsumtif millennial.

Menurut hasil riset, millennial lebih menyukai kegiatan makan di luar, statistic membuktikan bahwa millennial semakin tidak membutuhkan pasar tradisional, millennial yang lebih memilih untuk membeli bahan makanan dan memasaknya sendiri akan menjadi kaum minoritas, tidak peduli tentang mahalnya biaya hidup mayoritas millennial merupakan generasi yang paling menyukai kegiatan makan di luar rumah. Artikel The Washington Post bahkan mengatakan bahwa millennial telah mengubah kebiasaan makan di dunia.

Berlawanan dengan sifat millennial yang memiliki kecenderungan makan makanan yang instant, keputusan millennial dalam membeli sebuah makanan sangat dipengaruhi oleh ke organikan sebuah makanan dan gizi yang dimilikinya. Millennial sadar betul tentang gizi sebuah makanan yang instant sehingga mereka tidak takut membeli makanan yang lebih sehat walaupun lebih mahal. Ke organikan makanan juga menjadi kontribusi besar, mengetahui kesadaran millennial tentang sustainability.

Millennial sangat menghargai pengalaman sehingga keunikan suatu makanan menjadi prioritas seorang millennial, bukan rasanya. Mereka menginginkan suatu pengalaman yang tidak hanya diingat, namun juga dibagikan kepada teman-teman dan keluarga mereka. Hal ini berlaku pada menu makanan yang aneh unik ataupun lucu, dan pelayanan atau cara makan yang unik.

Millennial bukan tidak peduli terhadap gaya hidup mereka, tidak sedikit kita lihat millennial yang rajin datang ke gym setelah hari kerja walau sebagian dipengaruhi oleh sifat narsis millennial yang mendalami bodybuilding, hasil penelitian bahkan mengatakan bahwa millennial peduli terhadap kesehatan mereka, walaupun tidak setinggi generasi pendahulu. Millennial hidup dijaman teknologi dengan entertainment yang tidak ada habisnya, selagi betul mereka peduli dan sadar tentang pentingnya aktivitas seperti olahraga, mereka dihadapkan dengan pilihan yang jauh lebih banyak dibanding generasi sebelumnya sehingga pada akhirnya mereka lebih memilih untuk menonton drama di rumah, main game, ataupun makan di luar. Kedengarannya hal tersebut dialami oleh semua generasi dan bukan alasan yang kuat, namun aktivitas yang disebutkan diatas di jaman ini bercabang lagi tanpa batas. Game tidak lagi sebuah aktivitas bermain jari, namun sudah memiliki cerita dan mampu memperangkap manusia dalam waktu yang lama. Drama ataupun film bukan merupakan media yang harus disewa melalui toko dvd dan sebagainya, namun sudah menjadi media streaming yang tidak ada batasnya.

Menurut CSIS, olahraga masih merupakan kegiatan yang paling menarik minat millennial di Indonesia, atau dengan kata lain kesadaran millennial akan olahraga cukup tinggi. Namun kegiatan olahraga ini pada banyak kasus tidak dapat dimaksimalkan oleh karena kurang dan mahalnya biaya sehingga mereka memilih opsi yaitu hobi yang lebih murah seperti misalnya menonton film atau bermain game. Banyaknya entertainment yang dapat diakses millennial 
mempengaruhi pilihan millennial sekalipun kesadaran millennial akan pentingnya olahraga cukup tinggi.

Millennial menurut berbagai sumber tidak seperti generasi sebelumnya, mereka menginginkan waktu lebih untuk hobi mereka dan kehidupan pribadi mereka sehingga kefleksibelan jam kerja merupakan suatu hal yang sangat dicintai millennial. Leisure time seperti statistic diatas merupakan aspek yang sangat penting dalam kehidupan millennial.

Walaupun terkesan demikian, millennial bukanlah pemalas, menurut statistic yang dibuat oleh HBR, mereka mau bekerja diluar jam kerja mereka, tidak seperti generasi sebelum mereka yang tidak akan bekerja setelah lewat jam kerja yaitu jem 5 atau 6 sore. Millennial menuntun kebebasan, cara berpikir dan penjadwalan masuk jam 8 pagi dan pulang jam 5 sore merupakan hal yang sudah kuno.

Millennial sangat terbuka kepada kehidupan nocturnal, dimana mereka dapat bekerja pada malam hari dan tidur pada pagi hari, cara hidup ini dapat membantu perkembangan ekonomi suatu negara karena hal ini berarti kegiatan ekonomi berlangsung non-stop. Selain keuntungan dimana malam hari sepi dan memberi ketenangan tersendiri, terdapat berbagai research yang mengatakan manusia yang hidup secara nocturnal memiliki kreativitas yang lebih dibanding manusia yang bangun pagi. Di Belanda dan Prancis hal ini sudah bukan merupakan sesuatu yang asing. Sehingga program yang mampu menjawab kebutuhan leisure millennial pada jam berapapun juga sama pentingnya untuk kehidupan millennial.

\section{Pasar}

Pasar memilki pengertian umum yaitu "salah satu dari berbagai sistem, institusi, prosedur . hubungan social dan infrastruktur dimana usaha menjual barang, jasa dan tenaga kerja untuk orang-orang dengan imbalan uang. Barang dan jasa dijual menggunakan alat pembayaran yang sah seperti uang fiat". Namun pasar telah berkembang dan dipelajari dari masa ke masa sehingga pengertian pasar terus berkembang ,

Setelah membaca pedapat pasar menurut para ahli, penulis dapat menyimpulkan bahwa secara arsitektur "Pasar merupakan space dimana terjadi interaksi jual beli antara penjual dan pembeli."

Pasar juga memiliki nama-nama lain yang didasarkan oleh kondisi yang dimiliki oleh pasar. Pasar memiliki 2 wujud, yaitu abstrak dan konkret atau non-fisik dan fisik. Secara umum masyarakat mengenal 2 bentuk fisik pasar, yaitu pasar tradisional dan modern. Pasar juga memiliki ruang lingkup yang berbeda-beda sehingga skala pasar dapat diketahui berdasarkan namanya, diantara lain adalah pasar local, nasional dan internasional. Selain ruang lingkup pasar juga dapat dikategorikan melalui barang yang diperjualbelikan yaitu pasar barang konsumsi dan produksi, maupun waktu penyelenggaraan pasar, yaitu pasar harian, mingguan, bulanan, tahunan dan temporer.

Secara umum generasi millennial mengenal tidak hanya 2 jenis pasar, namun 3 pasar, yaitu pasar tradisional, modern dan online. Pasar Tradisional merupakan pasar yang paling interaktif dan merupakan pasar yang hidup paling lama dibandingkan pasar modern dan pasar online. Pasar ini mengalami banyak perubahan bentuk, terdapat sejarah yang panjang melihat pasar yang awalnya sangat organik menjadi modular seperti yang kita lihat pada pasar tradisional di jaman millennial ini.

Pasar Modern memiliki interaksi antar penjual dan pembeli, namun lebih terbatas jika dibandingan dengan pasar tradisional. Pasar modern memperkuat elemen efisiensi pada pasar 
dan memberikan perlakuan lebih professional kepada produk. Display pasar ini modular sehingga penggunaan space yang lebih efektif dan memiliki zonasi yang jelas sehingga orientasi pengunjung lebih terarah.

Pasar Online merupakan pasar instant yang tidak berlebihan jika dikatakan dilahirkan oleh perilaku millennial. Pasar ini memutus interaksi face-to-face antar penjual dengan pembeli, dan pembeli dengan produk dengan menjanjikan pelayanan yang jauh lebih cepat. Pasar ini tidak membutuhkan wujud fisik, hanya dibutuhkan ruang untuk penyimpanan barang.

Bisa dilihat bahwa Pasar Online merupakan perkembangan dari Pasar Modern, namun dalam konteks efisiensi dan profit. Pasar Tradisional tidak akan mampu menang secara ekonomi, baik itu melawan pasar modern ataupun pasar online, namun pasar tradisional memiliki elemen interaktif yang tidak dimiliki pasar modern ataupun online dimana hal tersebutlah yang menjadi perbedaan utama yang tidak dimiliki pasar modern ataupun online.

\section{METODE}

Metode dimulai dengan mengumpulkan data dan melakukan analisis terhadap semua data yang dikumpulkan, data-data tersebut adalah data mengenai perkembangan dan sejarah pasar, perkembangan teknologi, perkembangan perilaku generasi ke generasi, bahkan perkembangan issue, analisis perkembangan ini dibatasi berdasarkan 4 generasi yang masih hidup pada generasi ini, yaitu Baby Boomer, Gen X, Gen Y (Millennials), dan Gen Z (PostMillennials), walau dalam proses menganalisis perkembangan teknologi dan issue penulis menganalisis sedikit lebih jauh ke belakang. Setelah proses analisis dilakukan dibuat matriks yang menghubungkan hasil analisis perkembangan issue dengan hasil analisis perkembangan teknologi dan issue dan menganalisis dampak yang ditimbulkan terhadap pasar. Melalui matriks ini penulis menemukan berbagai cara untuk merespon dampak yang ditimbulkan oleh perkembangan generasi terhadap perkembangan pasar.

Setelah melalui proses diatas pencarian site dapat dimulai. Proses pemilihan site dalam proyek ini tidak berdasarkan proses penunjukan melainkan melalui proses perbandingan site dimana penulis membandingkan 3 site yang dipilih berdasarkan kepadatan penduduk dan angka konsumsi perkapita yang didapat dari BPS (Badan Pusat Statistik). Proses perbandingan dilakukan dengan perbandingan nilai dimana parameter dan value setiap parameter penulis tentukan berdasarkan matriks

Setelah melalui proses seleksi site dan mendapatkan site yang ideal, survey lapangan segera dilaksanakan. Survey dilakukan setiap jam 04.00-09.00 untuk memantau jam sibuk, kemudian jam 11.00-12.00 untuk memantau kondisi setelah jam kerja pasar, dan pada jam 15.0017 .00 18.0019 .00 untuk melihat kondisi pasar dan sekitarnya. Proses survey dibagi 2, yaitu hari kerja (Senin-Jumat) dan hari libur (Sabtu-Minggu), untuk memantau perbedaan aktivitas dan intensitas pada 2 kondisi yang jauh berbeda. Proses menganalisis tapak dilakukan bersamaan dengan proses survey tetap berlangsung setelah proses survey.

Setelah melalui proses analisis dan survey lapangan, penulis mulai melakukan berbagai eksperimen dalam membentuk massing untuk pasar millennial tersebut. Massing tidak terbentuk berdasarkan intuitif sendiri, namun berdasarkan hasil sintesa analisis site dan berbagai factor lainnya seperti misalnya konsep dan eksperimen pengaturan zoning.

Dalam proses eksperimen massing metode yang penulis terapkan merupakan metode yang penulis kembangkan sendiri dalam proses berarsitektur. Penulis selalu memulai dari konsep dalam membentuk setiap massa kemudian memperkuat salah satu elemen sintesis dari berbagai hasil sintesis tapak. Proses zoning dilakukan pada tahap tahap yang berbeda, pada beberapa massa zoning dilakukan diawal sebelum dilakukan proses massing dan pada beberapa massa dilakukan sebaliknya, hal ini bertujuan untuk memunculkan berbagai massing yang memiliki urutan desain yang berbeda dan memunculkan penyelesaian yang berbeda pula sehingga penulis bisa memilih langkah manakah yang terbaik dari berbagai perspektif. Setelah 
proses eksperimen massing selesai dan massing final sudah dipilih, dilakukan berbagai revisi sebelum akhirnya memasuki proses penggambaran yang merupakan tahap akhir dalam metode ini.

\section{DISKUSI DAN HASIL}

Metode yang penulis pakai dalam membentuk matriks menghasilkan berbagai cara untuk merespon perilaku millennial dan jawaban yang dibutuhkan untuk membangun pasar millennial. Hasil yang didapatkan dapat berupa program dalam proyek arsitektur, skala tentative proyek, inspirasi dalam konsep desain, kriteria pasar secara tentative dan lain-lain.

Setelah melalui proses penulisan pada akhirnya Pasar Dutamas menjadi site dimana proyek akan dibangun. Mengapa pasar tradisional dipilih oleh penulis dan bukan justru mencari lahan yang secara eksisting kosong atau bukan merupakan pasar? Melalui matriks yang dibuat oleh penulis, dapat disimpulkan bahwa pasar tradisional jika tidak mengikuti perkembangan jaman akan musnah dengan sendirinya, terutama ketika terjadi perputaran generasi berikutnya dimana baby boomer sudah tidak ada.

Setelah melalui proses diatas, dari proses pengumpulan data sampai proses penggambaran , penulis dapat menarik statement yang dihasilkan oleh proses tersebut.

"Pasar Tradisional akan musnah jika dibiarkan tetap seperti ini, ketika terjadi perputaran generasi dimana baby boomer sudah tiada, pasar tradisional di Indonesia akan hilang." Statement ini menjadi alasan dibalik pemilihan tapak yang menggunakan pasar tradisional eksisting.

"Pasar pada jaman millennial masih membutuhkan ruang fisik, interaksi langsung antara penjual dengan pembeli, begitu juga antara produk dan pembeli masih dibutuhkan oleh generasi millennial." Statement ini muncul setelah melihat issue yang dihasilkan oleh pasar online di jaman millennial ini.

\section{Program}

Seperti yang telah dibahas pada akhir bab 3 atau lebih tepatnya bab metode, proses diskusi yang menghasilkan metode tersebut menghasilkan berbagai hasil baik hal tersebut berupa program, massing, atau bahkan statement yang wujudnya alternatif, revisi atau merupakan hasil final. Berikut adalah penjabaran hasil yang diperoleh melalui proses panjang tersebut. Dalam proses matriks yang merupakan tahap pertama dalam metode proyek ini, muncul berbagai jawaban untuk aspek-aspek yang beragam yang kemudian diseleksi dan dibatasi sesuai dengan skala proyek. Program-program yang dihasilkan juga beragam dan setelah dilakukan proses seleksi, pasar millennial ini memiliki program-program seperti berikut.

a. Split-Level Traditional Market

Program ini lahir dari demand millennial terhadap experience yang unik. Sekalipun Pasar tradisional memang disusun secara modular namun permainan level ini menghembuskan sesuatu yang baru terhadap aktivitas jual-beli di pasar tradisional pada umumnya.

b. Menu Digital Gallery

Program ini lahir dari habit millennial yang serba instant namun disaat yang sama juga memperhatikan ketertarikan millennial terhadap interaktivitas dan experience yang baru. Hal ini mendorong millennial untuk datang dan menikmati aktivitas membeli dan memilih menu yang akan dinikmati dengan style yang menyerupai art gallery. Perlu ditekankan bahwa millennial rela menempuh jarak dan mengeluarkan uang untuk mengalami sesuatu yang unik, suatu pengalaman yang share-worthy.

c. Human Generator Gym

Program ini lahir dari isu kesehatan millennial yang diimbangi dengan kekhawatiran millennial akan biaya hidup, lifestyle yang dimiliki millennial mendorong asupan gizi mereka yang memburuk dan memudahkan mereka untuk memperoleh badan yang kurang 
sehat, untuk mengimbangi hal tersebut tentu saja diperlukan olahraga terutama dalam wujud cardio. Namun sifat konsumtif millennial bertabrakan dengan hal ini dimana selain mereka memiliki lingkup entertainment yang luas, mereka juga khawatir akan pengeluaran mereka.

d. Co-Storage Room

Program ini lahir dari isu habit sharing millennial pedagang tidak selamanya generasi sebelum millennial, generasi millennial juga akan masuk ke dalam pekerjaan ini sehingga sharing perlu dipertimbangkan dalam ruang kerja millennial, seperti layaknya co-working space, co-storage room merupakan ruang dimana supply bahan dapat diakses oleh semua kios makanan tersebut. Wujud kios menggunakan standar supermarket, dan kios ini bertujuan untuk mempererat hubungan antara pedagang sehingga lebih kooperatif dalam berbagai hal

e. E-clothing Store

E-clothing store merupakan toko display yang interaktif secara digital, program ini dibuat dengan tujuan untuk memperpanjang perjalanan sehingga aktivitas menunggu makanan tidak terasa. Seperti Menu Digital Gallery program ini juga lahir dari habit millennial yang serba instant namun disaat yang sama juga memperhatikan ketertarikan millennial terhadap interaktivitas dan experience yang baru.

f. Food Market

Diversitas Menu merupakan salah satu daya Tarik food market ini sehingga 50 Menu khas Indonesia yang didapat melalui CNN Indonesia menjadi syarat minimal jumlah menu yang diperjualbelikan, sedangkan daya Tarik utamanya jusrtru adalah perjalanan yang dibangun oleh digital menu gallery dan E-clothing Store.

g. Merchant \& Worker Education Room

Program ini lahir dari perkembangan teknologi, isu mengenai interaksi social, pentingnya edukasi dan demand millennial terhadap experience yang unik. Edukasi terhadap teknologi terhadap pedagang pada era millennial sangatlah penting, terutama program ini juga mengajarkan psikologi manuisa kepada pedagang sehingga mereka dapat memiliki ilmu yang diperlukan untuk berinteraksi dengan baik pada kaum millennial. Program ini juga mengajarkan tentang luasnya menu sehingga pedagang dapat meimprovisasi menu yang mereka miliki dan menarik millennial yang menyukai customisasi makanan

\section{Konsep \& Desain Pasar Millennial}

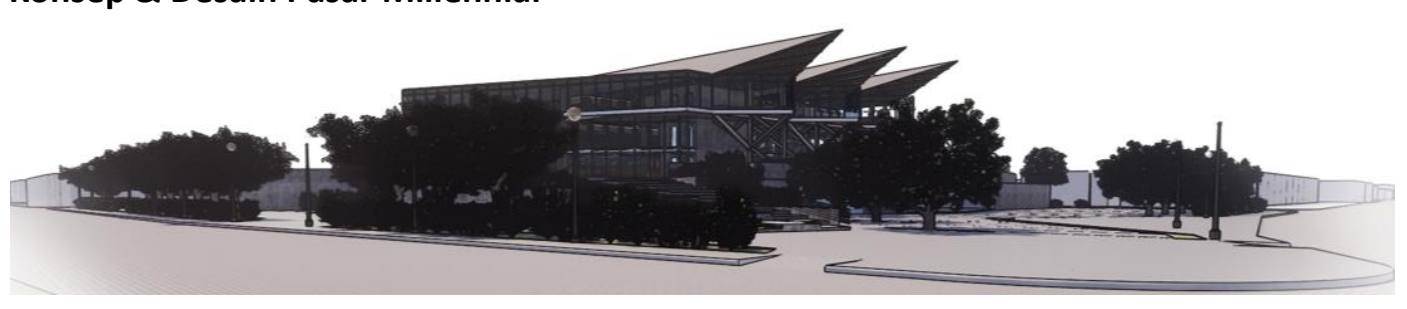

Gambar 1. Bentuk Arsitektural Proyek Sumber: Penulis, 2019

Proyek ini memiliki bentuk arsitektural yang tampak pada gambar 1, dimana bentuk tersebut merupakan hasil akhir dari eksperimen massing dan konsep yang sudah dijelaskan secara rinci pada bab metode. Proyek ini memiliki konsep "Past-Present-Future" yang muncul dari argumen mengenai pengaruh perilaku millennial terhadap pasar, bagaimana keberadaan millennial sanggup menghapus bentuk pasar secara fisik dan menjadikannya suatu aplikasi serba online yang tidak memerlukan space untuk didatangi. Konsep ini ingin mewujudkan perkembangan pasar secara arsitektur yang memperlihatkan bagaimana ketika millennial datang dan segalanya berubah. 

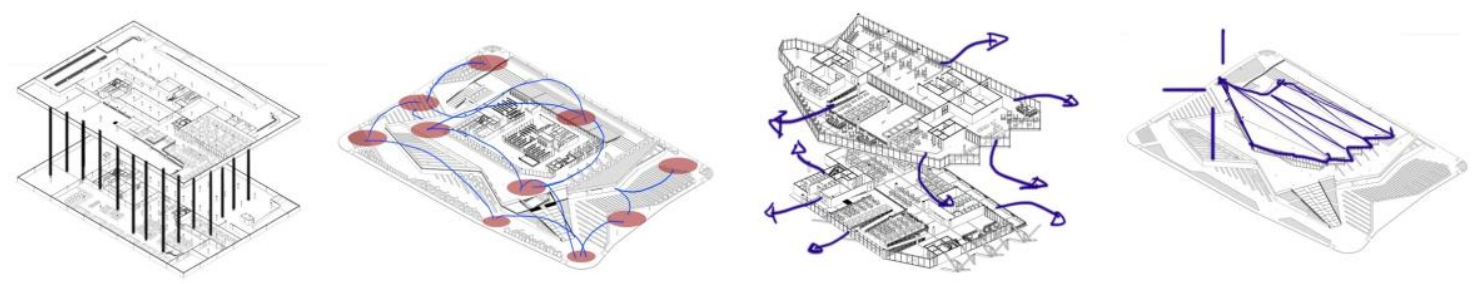

Gambar 2. Design Scheme

Sumber: Penulis, 2019

Proses dimulai dengan menerjemahkan konsep secara zoning, dimana "Past-PresentFuture" diterjemahkan melalui zoning. Kemudian proses berlanjut ke design scheme yang dapat terlihar di gambar 2. Design scheme diatas memiliki makna masing-masing yang semua bergerak atas dasar konsep dan respon terhadap tapak.

Scheme 1 - Bentuknya yang modular menggambarkan pasar pada era pra-millennial yang cenderung kaku, nuansa kaku dipertegas dengan pemakaian beton ataupun finishing beton sebagai material utama. Kemudian demi Meminimalisir perbedaan skyline basement dibuat 2 lantai.

Scheme 2 - Nodes yang terkoneksi dan nodes yang terbentuk dari koneksi membentuk public space yang menggambarkan pasar era millennial yang bebas dan serba terkoneksi. Kemudian scheme ini merespon tapak dengan mengalirkan nodes pada lingkungan dan memperhijau lingkungan

Scheme 3 - Transparansi yang diekspresikan melalui pemakainan material kaca menjelaskan era millennial yang serba terekspos, atau public. Penggunaan material kaca mengurangi kesan massa yang padat dan juga memperlihatkan aktivitas manusia keluar sehingga site dan lingkungannya terlihat lebih hidup melalui aktivitas yang terekspos.

Scheme 4 - Bentuk atap yang tidak menentu arahnya menggambarkan masa depan yang tidak terspekulasi. Kemudian bentuk merespon tapak dan lingkungan yang membutuhkan landmark.

Design Scheme menggambarkan ekspresi desain dan sintesis tapak secara bertahap, menghasilkan sebuah diagram yang menggambarkan hasil desain secara general. Diagram aksonometri exploded yang terlihat pada gambar 3 disamping memperlihatkan secara lebih detail bagaimana hasil akhir dari bentukan proyek tersebut.

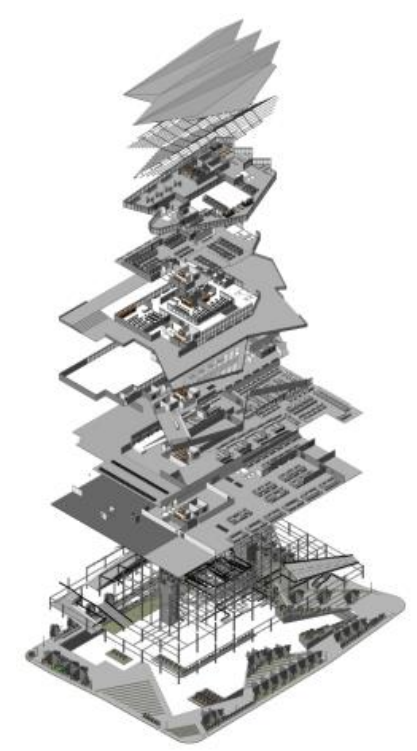

Gambar 3. Exploded Axonometry

Sumber: Penulis, 2019 
Diagram dari bawah ke atas menjelaskan mengenai layout landscape yang dibuat dengan memperhatikan nodes, sehingga tercipta sebuah ruang yang mengarahkan pedestrian untuk masuk ke dalam pasar millennial ini. Diagram Struktur dapat terlihat setelah layout landscape, dimana penggunaan material beton dan baja mendominasi struktur proyek ini. Setelah diagram stuktur terlihat aksonometri 3d denah dari level b2 sampai level terakhir, yang kemudian diakhiri dengan struktur atap.

Gambar 3 menjelaskan mengenai skema perjalanan dari sebuah sistem pada pasar millennial yang merupakan rangkaian program yang tersusun untuk menciptakan sebuah pengalaman yang cukup spesifik, yaitu adalah sistem penjualan food market, dan sistem penjualan pasar tradisional.

Sistem penjualan food market merupakan sistem yang didesain sehingga millennial merasakan interaktivitas dan pengalaman yang baru, yang akan menarik millennial untuk datang dan menikmati pengalaman yang berbeda. Interaktivitas tersebut dilengkapi dengan

Setelah melalui entrance dan diarahkan masuk, pengunjung akan disambut oleh displaydisplay menu secara digital, kemudian sampai ke space dimana pemesanan secara digital dapat dilaksanakan. Pemesanan dilakukan melalui layar secara touchscreen dan online, yang dilengkapi dengan informasi mengenai waktu yang diperlukan sehingga diketahui waktu yang diperlukan untuk sampai ke food market dengan makanan yang sudah tersedia. Proses menunggu diganti dengan perjalanan yang diberikan pada e-clothing store, toko baju dimana pengunjung bisa mencoba-coba baju secara digital setelah merasakan kualitas material yang terdisplay. Kemudian setelah itulah pengunjung dapat menikmati makanan mereka di food market yang berada 1 level diatas e-clothing store dan 2 level diatas menu digital gallery.
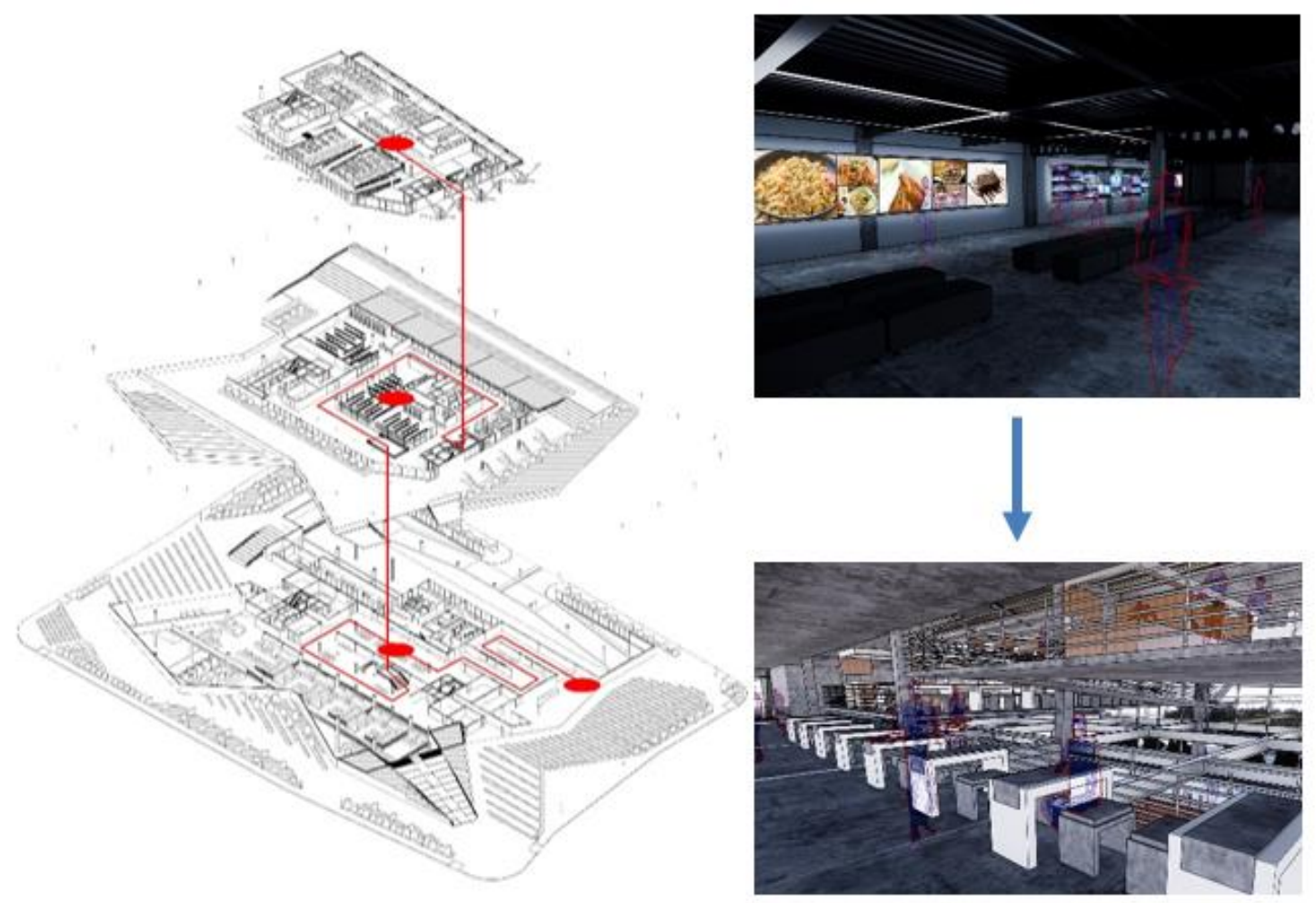

Gambar 4. Skema perjalanan entrance-menu digital gallery-food market (kiri), menu digital gallery (kanan atas) \& food market (kanan bawah)

Sumber: Penulis, 2019 


\section{KESIMPULAN DAN SARAN \\ Kesimpulan}

Kesimpulan proyek ini adalah Pasar Millennial; "Pasar yang merespon perilaku millennial”. Pasar yang tepat untuk generasi millennial bukanlah pasar online yang serba instant yang memanjakan millennial, melainkan dengan menciptakan ruang dan program interaktif yang memberikan rangkaian kegiatan yang menarik sehingga menghasilkan perasaan instant. Pasar tidak boleh kehilangan ruang fisiknya, interaksi pada pasar boleh berkembang seiring perkembangan jaman, namun interaksi tidak boleh hilang pada jaman apapun.

\section{Saran}

Pemecahan masalah dan pemilihan program yang penulis pilih dari sekian banyak opsi penulis nilai sudah tepat. Namun selepas itu, proyek ini bisa lebih baik lagi jika pengolahan food market dieksekusi dengan lebih millennial, penulis terlalu terpaku dengan aspek ekonomis sehingga pengolahan massa itu sendiri terganggu. Secara teknikal juga desain pasar tradisional masih memiliki banyak masalah, terutama dari segi ventilasi udara dan pencahayaan alami.

\section{REFERENSI}

Badan Pusat Statistik. (2019). Rata-Rata Konsumsi per Kapita Seminggu Beberapa Macam Bahan Makanan Penting, 2007-2018. Retrieved February 19, 2019, from https://www.bps.go.id/statictable/2014/09/08/950/rata-rata-konsumsi-per-kapitaseminggu-beberapa-macam-bahan-makanan-penting-2007-2017.html

CSIS. (2017). Survey Nasional Ada Apa dengan Milenial? Orientasi Sosial, Ekonomi dan Politik. Retrieved February 13, 2019

Jenkins, R. (2018). This Is Why Millennials Care so Much About Work-Life Balance. Retrieved February 15, 2019, from https://www.inc.com/ryan-jenkins/this-is-what-millennials-valuemost-in-a-job-why.html

Love, T. (2018). This gym gets its power from your workout. Retrieved February 17, 2019, from https://www.weforum.org/agenda/2018/03/this-new-eco-gym-is-powered-by-yourworkout

Nielsen. (2015). Global Generational Lifestyles. Retrieved February 15, 2019, from https://www.nielsen.com/tw/en/insights/report/2015/global-generational-lifestyles/

Peta Zonasi dan Tata Ruang Jakarta. (n.d.). Retrieved February 26, 2019, from http://www.sindikat.co.id/zonasi

Rosenbloom, C. (2018). 9 Ways Millennials Are Changing The Way We Eat. Retrieved February 21, 2019, from https://www.washingtonpost.com/lifestyle/wellness/9-ways-millennialsare-changing-the-way-we-eat/2018/02/20/6bb2fe60-11eb-11e8-8ea1c1d91fcec3fe_story.html?noredirect=on\&utm_term=.8df198972a90

Sachs, G. (2019). Millennials Coming of Age. Retrieved February 13, 2019, from https://www.goldmansachs.com/insights/archive/millennials/

Whittaker, B. (2018). Identity Crisis. Retrieved February 14, 2019, from https://www.thedigitalline.co.uk/2018/08/19/the-label-generation/

Zakky. (2018). Pengertian Pasar Menurut Para Ahli dan Definisinya Secara Umum. Retrieved February 21, 2019, from https://www.zonareferensi.com/pengertian-pasar 